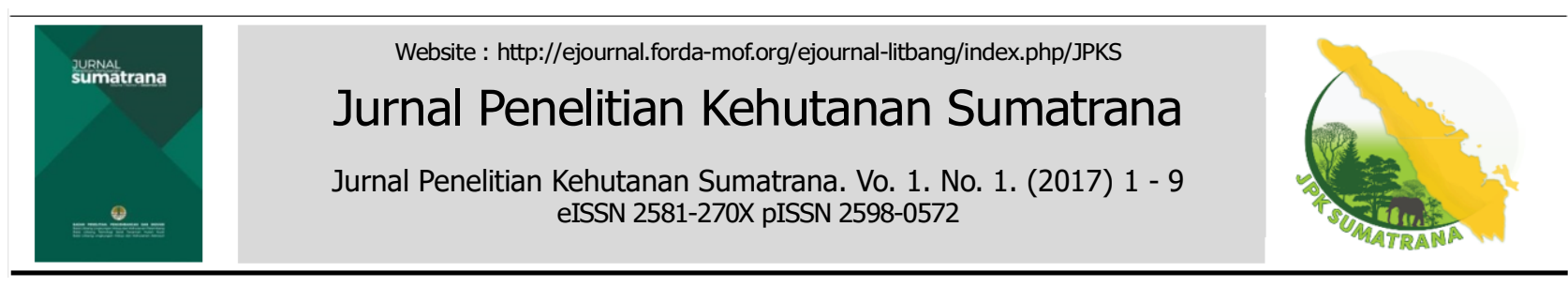

\title{
Faktor-faktor Fenotipe dan Lingkungan Penentu Produktivitas Resin Kemenyan Toba (Styrax sumatrana J. J. Sm)
}

\section{(Determinant Factors for Incense Productivity in Styrax sumatrana J. J. Sm based on Phenotypic and Environmental Characteristics)}

\section{Aswandi Anas ${ }^{1 *}$, Cut Rizlani Kholibrina ${ }^{1}$}

${ }^{1}$ Balai Penelitian Pengembangan Lingkungan Hidup dan Kehutanan Aek Nauli

Jl. Raya Parapat Km 10,5 Sibaganding Parapat Sumatera Utara HP. +6281314762472

*Email: rizlanicut@gmail.com

\author{
Article History: \\ Received 17 February 2017; Received in revised form 1 March 2017; \\ Accepted 18 Agust 2017; Available online since 30 Sept 2017
}

\begin{abstract}
ABSTRAK
Penelitian ini bertujuan untuk mengetahui faktor-faktor penentu produktivitas getah kemenyan toba Styrax sumatrana. Faktor-faktor yang diukur dibatasi pada karakteristik fenotipe dan karakteristik lingkungan tegakan dari berbagai hutan kemenyan di Kabupaten Humbang Hasundutan, Tapanuli Utara dan Pakpak Bharat, Provinsi Sumatera Utara pada tahun 2012-2015. Karakteristik fenotipe yang diukur adalah diameter, tinggi, umur, percabangan, warna kulit, tebal kulit, pembungaan dan keberadaan buah. Karakteristik lingkungan yang diukur adalah ketinggian tempat, temperatur, kelembaban relatif, intensitas cahaya, kerapatan tegakan, intensitas pemeliharaan dan pola penanaman. Produktivitas getah diukur dari rata-rata berat getah pohon contoh pada setiap panen. Hasil analisis tandan menunjukkan terdapat empat kelompok kinerja pengelolaan hutan kemenyan yang menggambarkan tingkat produktivitas resin, intensitas pengelolaan, perbedaan kondisi lingkungan dan penampakan fenotipe tegakan kemenyan. Hasil analisis diskriminan diperoleh empat faktor penentu produktivitas getah yakni warna kulit batang (34\%), jumlah penampakan bunga (20\%), kelembaban relatif (23\%), dan intensitas cahaya di bawah naungan (23\%). Faktor-faktor ini memiliki konsekuensi terhadap teknik silvikultur yang diterapkan seperti pola pencampuran dan pengaturan jarak tanam.
\end{abstract}

Kata kunci: Analisis tandan, analisis diskriminan, kulit batang, pembungaan, pengaturan jarak tanam

\section{ABSTRACT}

This study was aimed to identify the determinant factors of incense productivity of Styrax sumatrana. The measurement factors were phenotype and environmental characteristics from various forest stands in Humbang Hasundutan, North Tapanuli and Pakpak Bharat, North Sumatra Province. The phenotype characteristics were measured such as diameter, height, age, branching, barck color and thickness, flowering and fruits presence. Environmental characteristics were measured such as altitude, temperature, relative humidity, light intensity, stand density, intensity of maintenance and planting patterns. Resin productivity was measured from the average of harvest weight for each sample tree. The results of cluster analysis showed that there are four groups of forest management performances which described the level of productivity, management intensity, differences in environmental conditions and the appearance of styrax stands phenotypes. The result of discriminant analysis identified four determinants factors that influenced the resin productivity as well as the color of the bark (34\%), the number of sightings of flowers (20\%), relative humidity (23\%), and the light intensity in the shade (23\%). These factors have consequences for silvicultural techniques were applied such as mixing patterns and spacing.

Keywords: Cluster analysis, determinant analysis, bark color, flowering, spacing 


\section{PENDAHULUAN}

Kemenyan adalah getah atau resin yang dihasilkan pohon kemenyan (Styrax spp). Sejarah pengelolaan kemenyan di Tapanuli Sumatera Utara telah berlangsung sejak abad ke-17, serta telah memberikan kontribusi sebesar 70\%-75\% terhadap perekonomian petani (Sianipar \& Simanjuntak, 2000). Pohon kemenyan dikelola dalam bentuk hutan atau kebun campuran. Terdapat empat jenis kemenyan penghasil getah bernilai ekonomis, namun hanya dua jenis utama yang disadap yaitu kemenyan toba ( $S$. sumatrana J.J.Sm) dan kemenyan durame ( $S$. benzoin Dryand). Di antara keduanya, kemenyan toba lebih disukai karena memiliki kualitas getah yang lebih baik (padat dan jernih) serta harga jualnya relatif lebih tinggi (Kholibrina, 2012).

Permintaan getah kemenyan tetap tinggi namun produktivitasnya menurun. Di tahun 2008, produktivitas getah kemenyan mencapai 6.060 ton/ha, menurun hingga 4.620 ton/ha di tahun 2012 (BPS Sumut, 2013). Penurunan produktivitas disebabkan penurunan populasi akibat penebangan, umur tanaman tua dan permudaan yang mengandalkan regenerasi alam. Konversi dan penebangan mengakibatkan penurunan luas tegakan dari 24.077 ha di tahun 2007 menjadi 22.005 ha di tahun 2012 (BPS Sumut, 2013). Penurunan produktivitas terjadi cukup signifikan hingga 1.440 ton/ha selama empat tahun terakhir. Pengetahuan perbanyakan tanaman yang rendah dan waktu perkecambahan yang lama (8-9 bulan) menyebabkan petani hanya mengandalkan permudaan alami (Kholibrina, 2013). Belum banyak upaya yang berhasil dilakukan untuk meningkatkan produktivitas, sehingga diperlukan terobosan baru. Salah satu terobosan untuk mempercepat diperolehnya sumber bibit unggul adalah melalui rintisan koleksi sumberdaya genetik melalui kegiatan karakterisasi pohon plus "bocor getah". Istilah "bocor getah" diperkenalkan pada jenis tusam (Pinus merkusil) yang mampu memproduksi getah pinus dengan produktivitas tinggi seperti dilaporkan oleh Susilowati et al., (2013).

Karakterisasi pohon plus bocor getah dimulai dengan kajian variabilitas dan stratifikasi data pohon kemenyan yang memiliki produktivitas tinggi. Struktur produksi getah dan struktur pertumbuhan mencerminkan pengaruh faktor tempat tumbuh, sifat genetika pohon dan interaksi kedua faktor tersebut. Informasi tersebut sangat diperlukan dalam karakterisasi morfogenetika, anatomi kayu dan strategi perbanyakan kandidat bocor getah pohon kemenyan.

Karakterisasi morfogenetika dilakukan untuk menduga variabel genetika kandidat bocor getah melalui evaluasi fenotipe dan analisis genetika penanda molekuler. Pohon plus bocor getah merupakan hasil survei morfologi yang cenderung dipengaruhi oleh interaksi dengan faktor lingkungan. Saat ini informasi morfogenetika dan analisis molekuler kandidat kemenyan bocor getah belum tersedia. Dalam hal ini, pada tahap awal diperlukan rangkaian penelitian untuk mendapatkan pola variabilitas yang muncul baik berdasarkan aspek morfologi maupun akibat pengaruh faktor lingkungan yang signifikan.

Penelitian ini bertujuan untuk mengetahui faktor-faktor penentu produktivitas getah kemenyan toba Styrax sumatrana. Faktor-faktor yang diukur dibatasi pada karakteristik fenotipe dan karakteristik lingkungan tegakan. Informasi faktor-faktor penentu produktivitas yang diperoleh diharapkan menjadi dasar pertimbangan dalam pengaturan teknik silvikultur kemenyan untuk mendorong peningkatan produktivitasnya.

\section{METODE PENELITIAN}

Penelitian dilaksanakan pada tahun 2012-2015 pada berbagai pola hutan kemenyan rakyat di Kabupaten Humbang Hasundutan, Tapanuli Utara dan Pakpak Bharat. Lokasi-lokasi tegakan kemenyan terpilih sebanyak 26 lokasi di 16 desa yang merupakan sentra kemenyan rakyat di Sumatera Utara. Lokasi penelitian beserta kodefikasi tegakan contoh ditunjukkan Gambar 1 dan Tabel 1. 
Tabel 1. Lokasi tegakan kemenyan terpilih dan kodefikasinya

Table 1. Location of selected styrax stands and the codefication

\begin{tabular}{|c|c|c|c|c|c|}
\hline No. & $\begin{array}{c}\text { Lokasi } \\
\text { (Location) }\end{array}$ & $\begin{array}{c}\text { Jumlah } \\
\text { Sampel } \\
\text { (Number of } \\
\text { Samples) }\end{array}$ & $\begin{array}{c}\text { Lokasi } \\
\text { (Location) }\end{array}$ & $\begin{array}{c}\text { Koordinat } \\
\text { (Geo positioning) }\end{array}$ & $\begin{array}{c}\text { Kodefikasi } \\
\text { (Codification) }\end{array}$ \\
\hline 1. & Aek Nauli & 2 & Pollung, $\mathrm{HH}$ & $\begin{array}{l}\text { N2.25888 E98.64756 (1450 mdpl) } \\
\text { N2.26070 E98.64747 (1444 mdpl) }\end{array}$ & HBS1, HBS2 \\
\hline 2. & Matiti & 2 & Dolok Sanggul, HH & N2.25898 E98.64656 (1450 mdpl) & HBS3, HBS4 \\
\hline 3. & Sosor Tambok & 2 & Dolok Sanggul, HH & N2.25861 E98.64769 (1443 mdpl) & HBS5, HBS6 \\
\hline 4. & Sibuluan & 2 & Onan Ganjang, $\mathrm{HH}$ & N2.25834 E98.64771 (1451 mdpl) & HBS7, HBS8 \\
\hline 5. & Sihikkit & 2 & Onan Ganjang, $\mathrm{HH}$ & N2.25835 E98.64771 (1451 mdpl) & HBS9, HBS10 \\
\hline 6. & Pussuk & 1 & Parlilitan, $\mathrm{HH}$ & N2.33465 E98.51826 (1442 mdpl) & HBS11 \\
\hline 7. & Simataniari & 1 & Parlilitan, $\mathrm{HH}$ & N2.15949 E98.67977 (1271 mdpl) & HBS12 \\
\hline 8. & Bonan Dolok & 2 & Sijamapolang, $\mathrm{HH}$ & N2.25862 E98.64757 (1425 mdpl) & HBS13, HBS14 \\
\hline 9. & Pancurnapitu & 2 & Tarutung, TU & $\begin{array}{l}\text { N1.95169 E99.01153 (1011 mdpl) } \\
\text { N1.95244 E99.01163 (1025 mdpl) }\end{array}$ & TPT1, TPT2 \\
\hline 10. & Simasom & 2 & Pahae Julu, TU & $\begin{array}{l}\text { N1.91663 E99.03938 (925 mdpl) } \\
\text { N2.02167 E98.96476 (962 mdpl) }\end{array}$ & TPT3, TPT4 \\
\hline 11. & Pohan Jae & 2 & Siborongborong, TU & $\begin{array}{l}\text { N2.17952 E99.06314 (1259 mdpl) } \\
\text { N2.18085 E99.06448 (1275 mdpl) }\end{array}$ & TPT5, TPT6 \\
\hline 12. & Tegahambing & 2 & Pangaribuan, TU & $\begin{array}{l}\text { N2.18085 E99.06448 (1273 mdpl) } \\
\text { N2.02683 E99.19009 (1270 mdpl) }\end{array}$ & TPT7, ТРT8 \\
\hline 13. & $\begin{array}{l}\text { Pergenteng-genteng } \\
\text { Sengkut }\end{array}$ & 1 & $\begin{array}{l}\text { Pergenteng-genteng } \\
\text { Sengkut, PB }\end{array}$ & N2.72698 E98.93717 (1194 mdpl) & PAK1 \\
\hline 14. & Sei Empat Rube & 1 & Sei Empat Rube, PB & N2.72735 E98.93686 (1092 mdpl) & PAK2 \\
\hline 15. & Salak & 1 & Salak, PB & N2.65845 E98.64768 (978 mdpl) & PAK3 \\
\hline 16. & Sitelu urang julu & 1 & Sitelu Urang Julu, PB & N2.67864 E98.67365 (988 mdpl) & PAK4 \\
\hline
\end{tabular}

\section{A. Prosedur Penelitian}

Penelitian dilakukan dengan mengukur karakteris tik fenotipe, lingkungan tegakan dan produktivitas getah yang dihasilkan. Tegakan terpilih mewakili keragaman pola pengelolaan hutan kemenyan yakni pola pencampuran tanaman, perawatan tegakan, kerapatan dan penampakan fenotipe tegakan. Pada setiap tegakan dibangun satu plot ukur berukuran 0,05 ha berbentuk lingkaran dengan jari-jari 12,62 m. Luasan plot contoh yang dibangun dinilai cukup memadai untuk analisa floristik pada hutan tropika (Hueteto et al., 2013 dan Netto et al., 2014).

Karakteristik fenotipe yang diukur adalah rata-rata tiga pohon terpilih yakni diameter, tinggi, umur, percabangan, warna kulit batang, tebal kulit, pembungaan dan keberadaan buah. Karakteristik lingkungan tegakan yang diukur adalah ketinggian tempat, temperatur, kelembaban relatif, intensitas cahaya, kerapatan tegakan, intensitas pemeliharaan, dan pola penanaman.
Produktivitas getah diukur dari rata-rata produksi getah pohon contoh pada setiap panen. Periode panen mengacu pada jangka waktu pemanenan getah kemenyan yang umumnya dilakukan yakni setiap enam bulan sekali. Secara rinci faktor-faktor yang diukur serta teknik pengumpulan datanya ditunjukkan Tabel 2.

Data hasil pengukuran ditabulasikan serta dirata-ratakan menurut masing-masing tegakan atau provenans. Faktor-faktor fenotipe dan lingkungan tegakan diukur melalui analisis diskriminan dengan metode stepwise. Metode stepwise mengeluarkan faktor-faktor yang terdeteksi saling kolinear (multikolinearitas), dengan sub metode mahalanobis distance untuk mengidentifikasi outlier (Aswandi et al., 2015; Sitorus et al., 2011). Koefisien yang diperoleh pada fungsi linear digunakan untuk mengetahui faktor yang memberikan sumbangan terbesar terhadap terjadinya perbedaan antar kelas, sehingga koefisien tersebut dapat digunakan untuk pembobotan terhadap faktor yang terpilih (Aswandi et al., 2015; Sitorus et al., 
2011; Priyanto, 2007). Analisis data meliputi analisis klaster (cluster analysis) dan analisis diskriminan menggunakan perangkat lunak IBM SPSS Statistic ver. 22.

Tabel 2. Faktor-faktor fenotipe dan lingkungan dan teknik pengumpulan data Table 2. The Phenotypic and environmental factors and data collection techniques

\begin{tabular}{|c|c|c|c|}
\hline & $\begin{array}{c}\text { Karakteristik } \\
\text { (Characteristics) }\end{array}$ & & $\begin{array}{l}\text { Teknik Pengumpulan Data } \\
\text { (Data collection techniques) }\end{array}$ \\
\hline \multirow[t]{9}{*}{ A. } & Fenotipe (Phenotypes) & & \\
\hline & Diameter $(X 1.1)$ & $\mathrm{cm}$ & $\begin{array}{l}\text { Rata-rata Dbh } 3 \text { pohon (PU } 0,05 \text { ha bentuk lingkaran } \\
r=12,62 \mathrm{~m} \text { ). }\end{array}$ \\
\hline & Tinggi $(X 1.2)$ & $\mathrm{m}$ & Rata-rata tinggi total 3 pohon di dalam plot ukur. \\
\hline & Umur $(X 1.3)$ & tahun & Wawancara dengan pemilik tegakan. \\
\hline & Percabangan $(X 1.4)$ & jumlah (N) & Perhitungan jumlah percabangan utama. \\
\hline & Warna Kulit batang $(X 1.5)$ & warna & Pengamatan warna kulit batang menurut tabel warna. \\
\hline & Tebal Kulit (X1.6) & $\mathrm{mm}$ & $\begin{array}{l}\text { Sampel kulit batang pada ketinggian } 20 \mathrm{~cm} \text { dari permukaan } \\
\text { tanah diukur dengan kaliper. }\end{array}$ \\
\hline & Jumlah Pembungaan $(X 1.7)$ & jumlah $(\mathrm{N})$ & $\begin{array}{l}\text { Pengamatan keberadaan bunga pada setiap percabangan: } \\
\text { nilai } 4 \text { (bunga ada pada }>3 / 4 \text { percabangan); nilai } 3 \text { (bunga } \\
\text { ada pada } 1 / 2-3 / 4 \text { percabangan); nilai } 2 \text { (bunga ada } 1 / 4-1 / 2 \\
\text { percabangan); dan } 1 \text { (bunga hanya pada }<1 / 4 \text { percabangan). }\end{array}$ \\
\hline & Jumlah Buah (X1.8) & jumlah (N) & $\begin{array}{l}\text { Pengamatan keberadaan buah pada setiap percabangan: } \\
\text { nilai } 4 \text { (buah ada pada }>3 / 4 \text { percabangan); nilai } 3 \text { (buah ada } \\
\text { pada } 1 / 2-3 / 4 \text { percabangan); nilai } 2 \text { (bunga ada } 1 / 4-1 / 2 \\
\text { percabangan); dan } 1 \text { (bunga hanya ada pada }<1 / 4 \\
\text { percabangan). }\end{array}$ \\
\hline \multirow[t]{8}{*}{ B. } & Lingkungan (Environment) & & \\
\hline & Ketinggian tempat (X2.1) & Mdpl & Pengukuran dengan altimeter dan GPS receiver. \\
\hline & Suhu/Temperatur (X2.2) & ${ }^{\circ} \mathrm{C}$ & $\begin{array}{l}\text { Pengukuran dengan termometer pada siang hari di bawah } \\
\text { tegakan kemenyan di dalam plot ukur. }\end{array}$ \\
\hline & $\begin{array}{l}\text { Kelembaban Relatif }(\mathrm{RH}) \\
\text { (X2.3) }\end{array}$ & $\%$ & $\begin{array}{l}\text { Pengukuran dengan hygrometer pada siang hari di bawah } \\
\text { tegakan kemenyan di dalam plot ukur }\end{array}$ \\
\hline & Intensitas Cahaya (X2.4) & $\operatorname{lux}$ & $\begin{array}{l}\text { Pengukuran dengan luxmeter pada siang hari di bawah } \\
\text { tegakan kemenyan di dalam plot ukur }\end{array}$ \\
\hline & Kerapatan tegakan $(X 2.5)$ & $\mathrm{N} / \mathrm{ha}$ & Jumlah semua tingkat pohon dan tiang dalam plot ukur. \\
\hline & Pemeliharaan (X2.6) & Intensitas & $\begin{array}{l}\text { Pengamatan intensitas pemeliharaan/pembersihan } \\
\text { tumbuhan bawah: nilai } 4 \text { (tumbuhan bawah/semak }<1 / 4 \\
\text { luas PU); nilai3 (tumbuhan bawah/semak } 1 / 4-1 / 2 \text { luas PU); } \\
\text { nilai } 2 \text { (tumbuhan bawah/semak }>2 \text { luas PU); nilai } 1 \text { (tidak } \\
\text { ada pembersihan tumbuhan bawah/semak). }\end{array}$ \\
\hline & Pola Penanaman (X2.7) & $\begin{array}{l}\text { Monokultur-c } \\
\text { ampuran }\end{array}$ & $\begin{array}{l}\text { Pengamatan pola penanaman: nilai } 4 \text { (campuran didominasi } \\
\text { kemenyan); nilai } 3 \text { (campuran komposisi seimbang } \\
\text { kemenyan dengan jenis lain); nilai } 2 \text { (campuran didominasi } \\
\text { jenis alami lain). }\end{array}$ \\
\hline \multirow[t]{2}{*}{ C. } & Produktivitas & & \\
\hline & Produksi getah $(Y)$ & g/pohon & $\begin{array}{l}\text { Rata-rata berat panen getah dari } 4 \text { pohon pada setiap petak } \\
\text { ukur pada setiap panen. Kelas produktivitas diberikan nilai } 1 \\
\text { (getah }<1000 \mathrm{~g} / \text { pohon) dan nilai } 2 \text { (getah }>1000 \mathrm{~g} / \text { pohon). }\end{array}$ \\
\hline
\end{tabular}

\section{HASIL DAN PEMBAHASAN}

\section{A. Klasifikasi Kinerja Pengelolaan Kemenyan}

Hasil klasifikasi menggunakan analisis tandan dengan metode Average Linkage (Between Groups) dengan interval jarak Euclidean menunjukkan terdapat empat kelompok kinerja pengelolaan hutan kemenyan di lokasi penelitian. Keempat kelompok ini menggambarkan gradasi pengelolaan, lingkungan, fenotipe tegakan dan produktivitas getah. Dendrogram yang diperoleh dari analisis tandan dapat dilihat pada Gambar 1. Kelompok A menggambarkan pengelolaan tegakan cukup intensif karena telah terdapat kegiatan pemeliharaan seperti pembersihan tanaman bawah dan penebasan semak lebih dari $\quad>50 \%$ hingga $75 \%$ serta jarak tanaman yang cukup teratur. Tegakan yang ada merupakan pola campuran yang didominasi kemenyan dengan rata-rata produktivitas getah $\geq 1000 \mathrm{~g} /$ pohon. Tegakan-tegakan yang termasuk dalam 
kelompok ini adalah provenan HBS1, HBS2, HBS3, HBS4, HBS5, HBS6, HBS11, TPT1, TPT2, TPT3, dan TPT4. Kelompok B merupakan tegakan-tegakan kemenyan yang dikelola kurang intensif, ditunjukkan pembersihan tegakan bawah dengan intensitas < 50\%. Tegakan kemenyan bercampur dengan tegakan alam sehingga jarak antar tanaman kemenyan tidak teratur. Rata-rata produktivitas getah $750-1000$ $\mathrm{g} /$ pohon. Kelompok ini terdiri atas provenan HBS7, HBS8 HBS9 HBS10, HBS12, TPT5, dan TPT6. Kelompok C menggambarkan tegakan-tegakan kemenyan yang dikelola tidak intensif, didominasi tegakan alam, serta rata-rata produktivitas getah $500-750$ $\mathrm{g} /$ pohon. Kelompok ini terdiri atas provenan TPT7, TPT8, PAK1, PAK2, PAK3, dan PAK4. Sedangkan kelompok D menggambarkan tegakan-tegakan kemenyan yang tidak dikelola intensif, didominasi tegakan alam, dan rata-rata produktivitas getah 750-1000 $\mathrm{g} /$ pohon. Tegakan-tegakan yang termasuk dalam kelompok ini adalah provenan HBS13 dan HBS14. Karakteristik pengelolaan pada berbagai kelompok kinerja pengelolaan ditunjukkan Tabel 3.

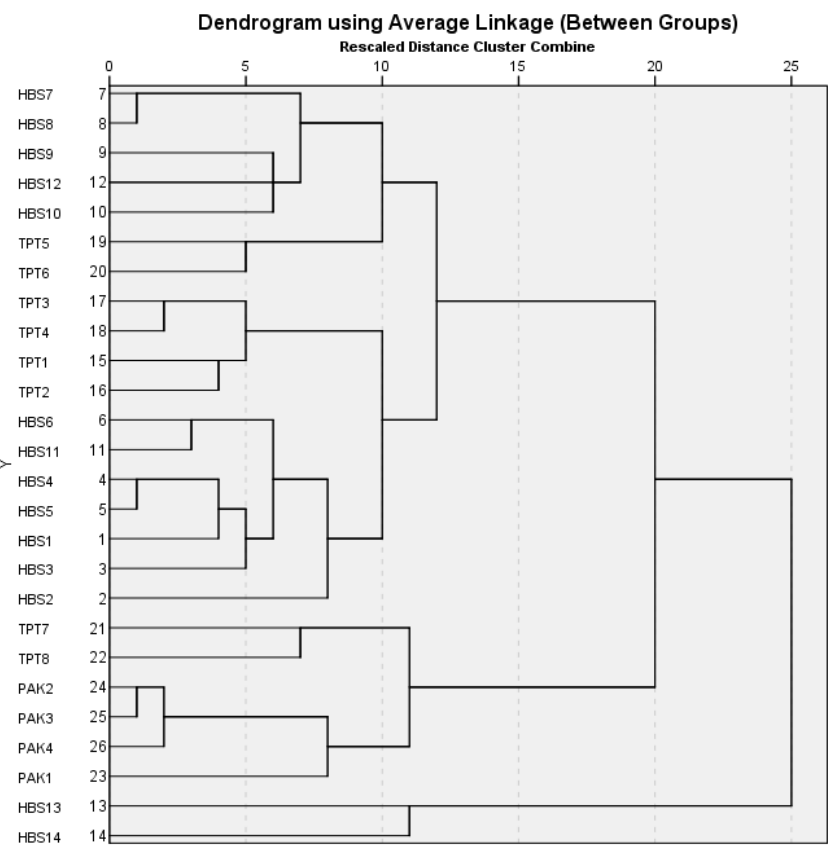

Gambar 1. Dendogram hasil analisa tandan (cluster analysis) kinerja pengelolaan hutan kemenyan

Figure 1. The dendrogram result obtained from cluster analysis of styrax forest management performances

Karakteristik fenotipe tegakan pada berbagai kelas kelompok kinerja pengelolaan ditunjukkan Tabel 4 dan Tabel 5. Rata-rata produktivitas getah tertinggi yakni 1.358 g/pohon terdapat pada kelompok A dan menurun gradual pada kelompok B (1.125 $\mathrm{g} /$ pohon), C (895 g/pohon), dan D (880 $\mathrm{g} /$ pohon). Produktivitas ini diukur pada periode panen enam bulan. Warna kulit batang pada kelompok A lebih gelap dibandingkan ketiga kelompok lainnya. Penampakan bunga dan buah pada kelompok A juga lebih banyak. Rata-rata ukuran diameter tertinggi terdapat pada kelompok A (umur 26 tahun) dan terendah pada kelompok $\mathrm{D}$ (umur 22 tahun). 
Tabel 3. Karakteristik pengelolaan hutan kemenyan pada berbagai kelompok kinerja Table 3. Characteristic of styrax forest management on various performance groups

\begin{tabular}{|c|c|c|}
\hline $\begin{array}{l}\text { Kelas Kinerja } \\
\text { (Performance } \\
\text { groups) }\end{array}$ & $\begin{array}{l}\text { Lokasi Tegakan/ } \\
\text { Provenan } \\
\text { (Location of stirax stands/ } \\
\text { provenance) }\end{array}$ & $\begin{array}{l}\text { Karakteristik Pengelolaan Hutan Kemenyan } \\
\text { (Characteristic of styrax forest management) }\end{array}$ \\
\hline$A$ & $\begin{array}{l}\text { HBS1, HBS2, HBS3, HBS4, } \\
\text { HBS5, HBS6, HBS11, TPT1, } \\
\text { TPT2, TPT3, TPT4 }\end{array}$ & $\begin{array}{l}\text { Pengelolaan cukup intensif, terdapat pemeliharaan, jarak } \\
\text { tanam cukup teratur, tegakan campuran didominasi } \\
\text { kemenyan. Produktivitas getah tinggi }\end{array}$ \\
\hline B & $\begin{array}{l}\text { HBS7, HBS8 HBS9 HBS10, } \\
\text { HBS12, TPT5, TPT6 }\end{array}$ & $\begin{array}{l}\text { Pengelolaan kurang intensif, bercampur dengan tegakan } \\
\text { alam, jarak tanaman tidak teratur. Produktivitas getah } \\
\text { sedang }\end{array}$ \\
\hline C & $\begin{array}{l}\text { TPT7, TPT8, PAK1, PAK2, } \\
\text { PAK3, PAK4 }\end{array}$ & $\begin{array}{l}\text { Pengelolaan tidak intensif, pemeliharaan kurang, jarak } \\
\text { tanaman tidak teratur, tegakan alam jenis lain dominan. } \\
\text { Produktivitas getah rendah-sedang }\end{array}$ \\
\hline D & HBS13, HBS14 & $\begin{array}{l}\text { Pengelolaan tidak intensif, pemeliharaan kurang, jarak } \\
\text { tanaman tidak teratur, tegakan alam jenis lain dominan. } \\
\text { Produktivitas getah sedang }\end{array}$ \\
\hline
\end{tabular}

Karakteristik lingkungan tegakan pada berbagai kelas kelompok kinerja pengelolaan hutan kemenyan ditunjukkan Tabel 5 . Rata-rata ketinggian tempat tertinggi terdapat pada kelompok B (1.350 mdpl) dan terendah pada kelompok C (996 mdpl).
Temperatur dan kelembabaan tertinggi terdapat pada tegakan-tegakan kelompok C. Intensitas cahaya tertinggi diukur di bawah naungan tegakan kemenyan kelompok $D$ (5.950 lux) dan terendah pada kelompok $A$ (2.622 lux).

Tabel 4. Karakteristik fenotipe tegakan pada berbagai kelompok kinerja pengelolaan Table 4. Phenotypic characteristic of styrax stands at various of forest management performance

\begin{tabular}{ccccccc}
\hline Kelompok & $\begin{array}{c}\text { Produktivitas } \\
\text { (Resin } \\
\text { (Gorups) } \\
\text { productivity) } \\
(\mathrm{g} / \text { pohon) } \\
(\mathrm{g} / \text { tree })\end{array}$ & $\begin{array}{c}\text { Dbh } \\
(\mathrm{cm})\end{array}$ & $\begin{array}{c}\text { Umur } \\
\text { (Age) } \\
\text { (tahun) } \\
\text { (year) }\end{array}$ & $\begin{array}{c}\text { Warna Kulit Batang } \\
\text { (Bark color) }\end{array}$ & $\begin{array}{c}\text { Tebal } \\
\text { Kulit } \\
\text { (Bark } \\
\text { thickness) } \\
(\mathrm{mm})\end{array}$ & $\begin{array}{c}\text { Penampakan } \\
\text { Bunga/Buah } \\
\text { (Flowering or } \\
\text { fruiting } \\
\text { presence) }\end{array}$ \\
\hline A & 1.358 & 28,45 & 26 & Cokelat kemerahan sedang-tua & 7,85 & Sedang-banyak \\
B & 1.125 & 28,23 & 27 & $\begin{array}{l}\text { Cokelat kemerahan } \\
\text { muda-sedang }\end{array}$ & 6,69 & Kurang-Sedang \\
C & 895 & 26,58 & 30 & Cokelat kemerahan muda & 6,33 & Kurang-Sedang \\
D & 880 & 22,40 & 22 & Cokelat kemerahan muda & 6,00 & Sedang \\
\hline
\end{tabular}

Tabel 5. Karakteristik lingkungan tegakan pada berbagai kelompok kinerja pengelolaan Table 5. The environment characteristics around the styrax stands at several forest management performance

\begin{tabular}{cccccccc}
\hline $\begin{array}{c}\text { Kelompok } \\
\text { (Groups) }\end{array}$ & $\begin{array}{c}\text { Elevasi } \\
\text { (Elevation) } \\
\text { (mdpl) }\end{array}$ & $\begin{array}{c}\text { Suhu } \\
(\text { Temperature) } \\
\left({ }^{\circ} \mathrm{C}\right)\end{array}$ & $\begin{array}{c}\text { RH } \\
\text { Relative } \\
\text { Humidity) } \\
(\%)\end{array}$ & $\begin{array}{c}\text { Intensitas } \\
\text { Cahaya } \\
\text { (Light } \\
\text { intensity) } \\
(\text { lux })\end{array}$ & $\begin{array}{c}\text { Kerapatan } \\
\text { (Density) } \\
(\mathrm{N} / \mathrm{ha})\end{array}$ & $\begin{array}{c}\text { Pomeliharaan } \\
\text { (tree } \\
\text { maintenance } \\
\text { patterns) }\end{array}$ & $\begin{array}{c}\text { Pola } \\
\text { Tanaman } \\
\text { (Planting } \\
\text { patterns) }\end{array}$ \\
\hline $\mathrm{A}$ & 1.264 & 25,07 & 79,30 & 2.622 & 555 & Cukup intensif & Campuran \\
B & 1.350 & 25,97 & 71,28 & 4.000 & 545 & Kurang intensif & Campuran \\
C & 996 & 29,75 & 82,45 & 4.483 & 630 & Tidak intensif & Campuran \\
D & 1.204 & 25,56 & 74,41 & 5.950 & 320 & Tidak intensif & Campuran \\
\hline
\end{tabular}




\section{B. Faktor penentu produktivitas getah}

Berdasarkan analisis multikolinearitas yang dilakukan, dideteksi empat faktor penentu produktivitas getah kemenyan yang tidak saling kolinear yakni: warna kulit batang $\left(X_{1}\right)$; jumlah penampakan bunga $\left(X_{2}\right)$ kelembaban relatif $(\mathrm{RH})\left(X_{3}\right)$, dan intensitas cahaya $\left(X_{4}\right)$. Berdasarkan analisis diskriminan diperoleh fungsi linear yakni $Y=$ $-0,974 X_{1}+0,563 X_{2}+0.651 X_{3}+0.676 X_{4}$ dengan signifikansi 0,00 yang fungsi diskriminan mempunyai kemampuan menjelaskan keragaman sebesar $100 \%$. Fungsi tersebut memiliki nilai eigenvalue yang tinggi yakni 3.797. Nilai eigenvalue yang tinggi (>1) menunjukkan fungsi yang diperoleh sahih (Aswandi et al., 2015; Priyanto, 2007; Correa-Metrio, 2010). Berdasarkan uji Wilks' Lambda, fungsi tersebut juga memiliki signifikansi yang tinggi $(p=0,00)$, dengan kemampuan menjelaskan keragaman hingga mencapai $100 \%$. Hal-hal ini menunjukkan bahwa fungsi yang terbentuk mampu mendiskriminasi yang baik.

Berdasarkan koefisien faktor-faktor yang memberikan sumbangan terbesar terhadap terjadinya perbedaan antar kelas dilakukan pembobotan masing-masing faktor yakni: warna kulit batang (34\%), jumlah penampakan bunga (20\%), kelembaban relatif $(\mathrm{RH})(23 \%)$, dan intensitas cahaya $(23 \%)$. Berdasarkan pembobotan tersebut, produktivitas getah kemenyan per pohon dipengaruhi oleh fenotipe warna kulit batang sebesar $34 \%$ dan jumlah penampakan bunga sebesar $20 \%$ serta pengaruh lingkungan dari faktor kelembaban relatif $(\mathrm{RH})$ sebesar $23 \%$, dan intensitas cahaya sebesar $23 \%$.

Pengaruh lingkungan dan genetik terhadap produktivitas getah atau resin yang dihasilkan juga ditunjukkan oleh jenis lain, diantaranya Tusam (Pinus merkusii). Akan tetapi pada jenis ini, berdasarkan pendekatan nilai heritabilitas, intensitas produksi getah lebih dipengaruhi oleh faktor genetika dibanding lingkungannya. Dalam hal ini aspek anatomi saluran resin dipertimbangkan lebih mempengaruhi produksi getah (Susilowati et al., 2013). Namun, pada pohon kemenyan toba, karakteristik saluran getah berbeda jika dibandingkan dengan jenis Tusam. Saluran getah kemenyan merupakan saluran getah traumatik yang disebabkan perlakuan mekanis atau serangan hama dan terletak pada bagian kayu (xylem). Tetapi dalam penelitian ini faktor genetika berdasarkan nilai heritabilitas tidak dilakukan.

Berdasarkan informasi yang diperoleh, untuk memperoleh kondisi optimal dalam pembangunan hutan rakyat kemenyan, dapat dilakukan rekayasa faktor lingkungan melalui penerapan teknik silvikultur yang tepat dalam pengaturan jarak tanam dan pemeliharaan tegakan. Pengaturan jarak tanam yang tepat akan menciptakan ruang dan intensitas cahaya yang cukup sehingga dapat mendorong proses pembungaan berjalan lebih baik. Intensitas pembungaan yang cukup menciptakan kondisi fisiologis yang ideal bagi produktivitas getah yang optimal (Kholibrina, 2015). Pengamatan menunjukkan bahwa terdapat korelasi antara intensitas pembungaan yang tinggi terhadap tingkat ketebalan dan kelekangan kulit batang yang memudahkan proses penyadapan getah. Dengan kulit yang lebih lekang, getah terkumpul lebih banyak dibalik kulit batang sehingga dapat meningkatkan hasil getah kemenyan yang dipanen. Selanjutnya, tegakan yang dipelihara dari gulma pengganggu akan mempengaruhi kelembaban relatif, temperatur dan intensitas cahaya yang mencapai tajuk tegakan.

\section{KESIMPULAN DAN SARAN}

\section{A. Kesimpulan}

Hasil analisis tandan menunjukkan terdapat empat kelompok kinerja pengelolaan hutan kemenyan yang menggambarkan tingkat produktivitas, intensitas pengelolaan, perbedaan kondisi lingkungan dan fenotipe tegakan kemenyan. Hasil analisis diskriminan mengidentifikasi empat faktor penentu produktivitas getah beserta bobotnya yakni warna kulit batang (34\%), jumlah penampakan bunga (20\%), kelembaban relatif $(23 \%)$, dan intensitas cahaya di bawah naungan (23\%). Informasi ini berguna untuk pengaturan teknik silvikultur yang paling sesuai seperti pola pencampuran dan jarak tanam. 


\section{B. Saran}

Mempertimbangkan sangat terbatasnya riset-riset yang berkaitan dengan peningkatan produktivitas hasil hutan bukan kayu endemik di sekitar Danau Toba, beberapa temuan awal yang diperoleh diharapkan ditindaklanjuti. Saluran getah kemenyan merupakan saluran getah traumatik yang disebabkan perlukaan mekanis maupun alamis terletak pada bagian kayu (xylem). Namun, belum diketahui hubungan kuantitas getah terhadap pelukaan batangnya, sehingga perlu dilakukan analisis lanjutan terhadap hal tersebut. Beberapa keterbatasan yang dihadapi dalam penelitian ini juga dapat diatasi dengan penambahan jumlah sampel dan perumusan metode pengumpulan data yang lebih efektif.

\section{UCAPAN TERIMA KASIH}

Ucapan terima kasih disampaikan
kepada Kepala Balai Penelitian
Pengembangan Lingkungan Hidup dan
Kehutanan Aek Nauli, Dinas Kehutanan dan
Perkebunan Kabupaten Humbang
Hasundutan dan Pakpak Bharat serta Dinas
Kehutanan Kabupaten Tapanuli Utara.

\section{DAFTAR PUSTAKA}

Aswandi, R. Sadono, H. Supriyo, dan Hartono. (2015). Faktor-faktor Penentu Kekritisan dan Pengembangan Kriteria Indikator Kekritisan Ekosistem Gambut Tropika di Trumon dan Singkil Provinsi Aceh. Jurnal Manusia dan Lingkungan, 21(3): 172-183

Badan Pusat Statistik Provinsi Sumatera Utara. (2013). Sumatera Utara dalam Angka 2013. Medan: BPS Provinsi Sumut.

Correa-Metrio, A., K.R.C. Torres, and M.B. Bush. (2010). Quantitifying Ecological Change through Discriminant Analysis: A Paleoecological Example from the Peruvian Amazon. Journal of Vegetation Science, 21 (4): 695-704.

Dinas Pertanian Humbahas. (2009). Laporan Kegiatan Tahunan. Dinas Pertanian Kabupaten Humbang Hasundutan
Provinsi Sumatera Utara.

Fernández, C.G. (2004). Benzoin, a resin produced by Styrax trees in North Sumatra Province, Indonesia. Forest products, livelihoods and conservation: case studies of non-timber forest product systems, volume 1-Asia, p.148.

Hueteto, G., Romain, G.K., Vlaere, S., Belarmain, F., Achille, E., Brice, S., Rodolphe, P. (2014). Effect of inventory plot patterns in the floristic analysis of tropical woodland and dense forest. African Journal of Ecology, 52 (3): 257-264.

Kholibrina, C.R. (2013). Eksplorasi Pengumpulan Materi Genetik Kemenyan Toba (Styrax sumatrana J.J.Sm sinonim S. parallelloneurum) untuk Populasi Dasar dan Populasi Pemuliaan. Prosiding Ekspose Hasil Penelitian Balai Penelitian Kehutanan Aek Nauli. Tema Peran Penelitian Kehutanan dalam Konservasi dan Rehabilitasi di Sumatera. Pusat Penelitian dan Pengembangan Konservasi dan Rehabilitasi. Medan, 28-29 Mei 2013.

Kholibrina, C.R. (2012). Strategi Pemuliaan dan Teknik Silvikultur Untuk Peningkatan Kualitas Kemenyan Toba ( $S$. sumatrana J.J.Sm Sinonim S. paralleloneurum). Prosiding Ekspose Hasil-hasil Penelitian Kehutanan. Tema Peran Penelitian Kehutanan dalam Konservasi dan Rehabilitasi di Sumatera. Pusat Penelitian dan Pengembangan Konservasi dan Rehabilitasi.

Kholibrina, C.R. (2015). Pembungaan Pohon Kemenyan Toba (Styrax sumatrana) di Arboretum Aek Nauli. Prosiding Ekspose Hasil Penelitian. Pusat Penelitian dan Pengembangan Hutan. Badan Litbang dan Inovasi.

Lemenih, M. and H. Kassa. (2008). Management guidelines for Boswellia papyrifera and its frankincense in Ethiopia. Center for International Forestry Research-Ethiopia, Addis Ababa, Ethiopia. 
Lemenih, M. and H. Kassa. (2011). Opportunities and challenges for sustainable production and marketing of gums and resins in Ethiopia. CIFOR, Bogor, Indonesia

Lemenih, M., S. Feleke, and W. Tadesse. (2007). Factors constraining the production and marketing of frankincense by local people in Metema district, North-Western Ethiopia. Journal of Arid Environments 71: 393-403.

Netto, S.P., Tello, C.R., Wandresen, R.R. (2014). Size and shape of sample units in native forest and plantations. Journal of Forestry. 4: 379-389.

Pretzsch, H., J. Dieler, and T. Rőtzer. (2012). Principles of Growth Partitioning Between Trees in Forest Stand Under Stress. In. R. Matyssek et al. (eds). Growth and Defense in Plants. Ecological Studies 220. Springer-Verlag Berlin Heidelberg.

Priyanto. (2007). Penerapan Analisa Diskriminan Dalam Pembedaan Kelas Umur Tegakan Pinus. J. Manajemen Hutan Tropika, 13 (3): 155-165.

Rijkers, T., W. Ogbazghi, M. Wessel, and F. Bongers. (2006). The effect of tapping for frankincense on sexual reproduction in Boswellia papyrifera. Journal of Applied Ecology 43: 1188-1195.

Sianipar, H. dan B. Simanjuntak. (2000). Isolasi dan Identifikasi Asam Sinamat dari Kemenyan Sumatrana. Media Farmasi 4 (1): 22-28.

Sitorus, S.R.P., Mashudi, dan O. Haridjaja. (2011). Pengembangan Kriteria dan
Klasifikasi Lahan Kritis serta Keterkaitannya dengan Produktivitas Lahan di Kabupaten Bogor. Prosiding Seminar Nasional Sumberdaya Lahan Pertanian. Balai Besar Penelitian dan Pengembangan Sumberdaya Lahan Pertanian. Kementerian Pertanian. Bogor, 30 November - 1 Desember 2010.

Susilowati, A., Supriyanto, Siregar, I.Z.,Wahyudi, I., and Corryanti. (2013). Genetic Variation, Heritability and Correlatiom between Resin Production Character of Pinus merkusii High Resin Yielder (HRy) in Cijambu Seedling Seed Orchard (SSO). Biotropia, 20 (20): 122-133.

doi: http://dx.doi.org/10.11598/btb.2013.30 .2.257.

Tilahun, M., L. Vranken, B. Muys, J. Deckers, K. Gebregziabher, K. Gebrehiwot, H. Hans Bauer, and E. Mathijs. (2012). Rural Households Demand for Frankincense Forest Conservation in Tigray: A Continent Valuation Analysis. BioeconomicsWorking Paper Series Working Paper 2012/2.

Vanclay, J.K. (1994). Modelling Forest Growth and Yield: Aplication to Mixed Tropical Forest. Wallingford: CAB International.

Van Wyk, M., Wingfield, B.D., Clegg, P.A. and Wingfield, M.J. (2009). Ceratocystis larium sp. nov., a new species from Styrax benzoin wounds associated with incense harvesting in Indonesia. Persoonia, 22, p.75. 